
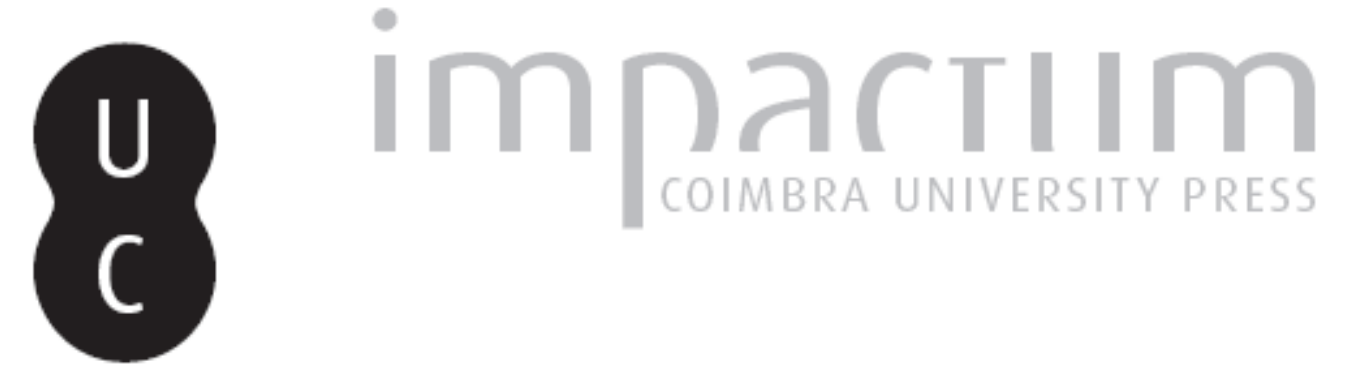

\title{
Revoltas contra os judeus no Portugal medieval
}

Autor(es): $\quad$ Tavares, Maria José Ferro

Publicado por: Imprensa da Universidade de Coimbra

URL persistente:

URl:http://hdl.handle.net/10316.2/43818

DOI:

DOl:https://doi.org/10.14195/2183-8925_6_3

Accessed : $\quad$ 26-Apr-2023 07:10:13

A navegação consulta e descarregamento dos títulos inseridos nas Bibliotecas Digitais UC Digitalis, UC Pombalina e UC Impactum, pressupõem a aceitação plena e sem reservas dos Termos e Condições de Uso destas Bibliotecas Digitais, disponíveis em https://digitalis.uc.pt/pt-pt/termos.

Conforme exposto nos referidos Termos e Condições de Uso, o descarregamento de títulos de acesso restrito requer uma licença válida de autorização devendo o utilizador aceder ao(s) documento(s) a partir de um endereço de IP da instituição detentora da supramencionada licença.

Ao utilizador é apenas permitido o descarregamento para uso pessoal, pelo que o emprego do(s) título(s) descarregado(s) para outro fim, designadamente comercial, carece de autorização do respetivo autor ou editor da obra.

Na medida em que todas as obras da UC Digitalis se encontram protegidas pelo Código do Direito de Autor e Direitos Conexos e demais legislação aplicável, toda a cópia, parcial ou total, deste documento, nos casos em que é legalmente admitida, deverá conter ou fazer-se acompanhar por este aviso.

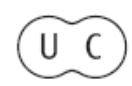




\section{REVISTA DE HISTORIA DAS IDEIAS 6}

\section{. \\ REVOLTAS E REVOLUCOEES}

*

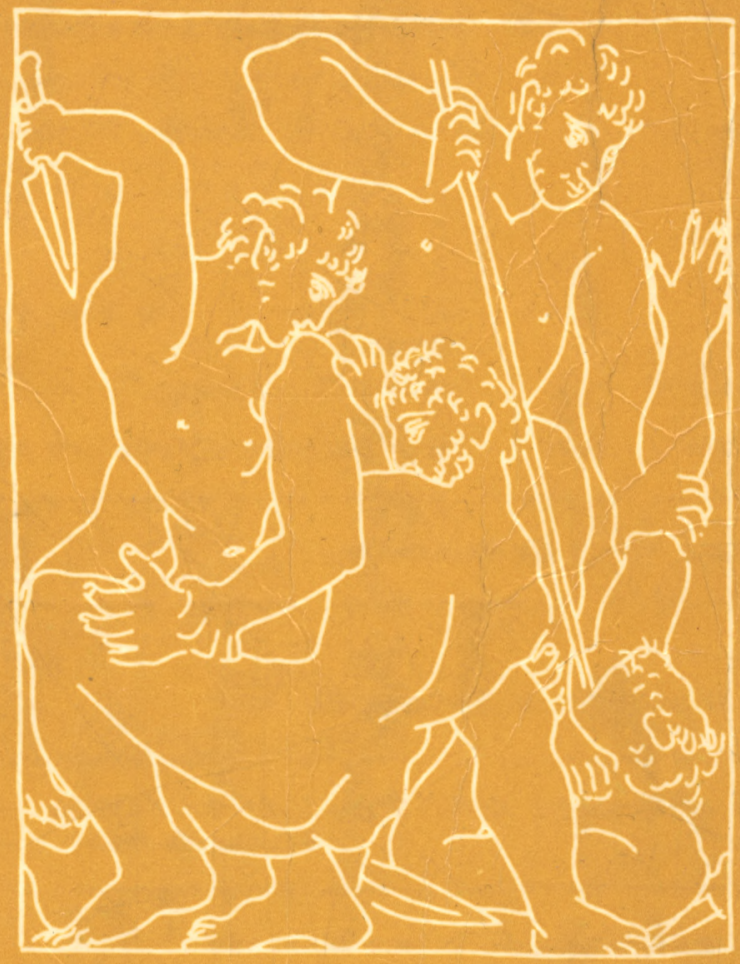

INSTITUTO DE HISTORIA E TEORIA DAS IDEIAS FACULDADE DE LETRAS 
MARIA JOSE FERRO TAVARES *

\section{REVOLTAS CONTRA OS JUDEUS NO PORTUGAL MEDIEVAL}

Ao contrário do que sucedeu na maior parte da Europa, os judeus encontraram em Portugal um clima de aceitação e de relacionamento pacífico, propício ao seu estabelecimento e difusão pelo reino. Raros foram, que o saibamos, os momentos em que o sentimento antijudaico tivesse explodido em levantamentos populares, acompanhados da destruição de pessoas e bens desta minoria religiosa.

No entanto, aquele não se encontrava ausente da mentalidade cristã, tendo permanecido em alguns jogos populares, como a festa do bispo Estêvão e a caca ao "porco pisco", e numa certa leitura do judeu como "infiel» e assimilado a Judas e ao povo deicida. Se a poesia de escárnio e maldizer ignorou este sentir de raiz religiosa, o mesmo já não sucederia com a obra de Gil Vicente e de alguns poetas do Cancioneiro Geral, contemporâneos já da expulsão dos judeus e do seu baptismo forçado, em $1497\left({ }^{1}\right)$.

Encontramo-lo também na legislação canónica e civil, a partir do século XIII onde se apresentava afirmada a supremasia do cristão sobre o judeu infiel o qual devia "servir» aquele. Mas, nas ordenações reais. a distinçãö eifitre a maioria cristã e a minoria judaica advinha das imposições do clero que procurava manter em Portugal os princípios definidos pelo IV concílio de Latrão, no respeitante à separação das gentes dos dois credos, e das cortes, onde os procuradores se manifestavam em termos de concorrência económica quer a

\footnotetext{
* Faculdade de Ciências Sociais e Humanas da Universidade Nova de Lisboa.

(') Veja-se sobre isto: Maria José P. Ferro Tavares, Os Judeus em Portugal no século XV, Lisboa, U.N.L. 1982, pp. 21-35.
} 
nível do empréstimo monetário, quer do comércio, quer do artesanato $\left({ }^{2}\right)$.

Nos raros levantamentos populares conhecidos, religião e rivalidade económica aparecem a par.

A mais antiga referência que encontramos à destruição de judeus e seus bens respeita ao reinado de Sancho I e teria sido praticada pelos cruzados na comunidade judaica de Lisboa $\left({ }^{3}\right)$. Aliás, o antijudaísmo dos movimentos cruzadísticos foi uma realidade, bem patente na aplicação do termo "infiel" ao judeu. Este era o «inimigo» que residia no interior da cristandade $\left({ }^{4}\right)$. Esta destruição foi, no entanto, segundo parece, estranha aos hábitos nacionais e até peninsulares.

Os séculos XIII e XIV até, pelo menos, ao seu último quartel decorreram sem qualquer alteração no comportamento entre a maioria cristã e a minoria judaica, de modo a concluir-se pela inexistência de qualquer espécie de levantamentos contra os judeus. A peste negra tão fértil, na Europa central e no levante peninsular, em provocar assaltos e a destruição de comunas inteiras $\left(^{5}\right)$, não teve aqui consequências, excepto talvez a obrigatoriedade do uso do sinal distintivo com D. Afonso IV e a separação do espaço judaico dentro do concelho, com o encerramento das judiarias que se começaria a manifestar com D. Pedro I $\left.{ }^{\beta}\right)$.

Durante o reinado de D. Fernando, os judeus portugueses sofreram mutilações diversas que, em alguns casos, provocaram até um abandono temporário ou não do local onde residiam. A guerra e os castelhanos foram os causadores directos da destruição, em 1373, das judiarias de Coimbra e de parte

(') Maria José P. Ferro, Os Judeus em Portugal no século XIV, I.A.C., Lisboa, 1970, pp. 52-54, 60-75 (2.a ed., Lisboa, Guimarães eds., 1979); Maria José P. Ferro Tavares, ob. cit., pp. 397-404 e cap. V; Maria José P. Ferro Tavares, «Judeus e mouros no Portugal dos séculos XIV e XV», Revista de História Económica e Social, n. ${ }^{\circ}$, Janeiro-Junho de 1982, pp. 75-89.

(') Fortunato de Almeida, História da Igreja em Portugal, 2. ${ }^{\text {a }}$ ed., Porto-Barcelos, Portucalense ed., 1967, vol. I, p. 206, nt. 8.

(4) Jean Delumeau, La peur en Occident, XIV-XVII siècles, Paris, Fayard, 1978, p. 278.

$\left({ }^{5}\right)$ Jean-Noel Biraben, Les hommes et la peste en France et dans les pays européens et méditerranéens, Paris-La Haye, Mouton, 1975, vol. I, pp. 57-65; Amada Lopez de Meneses, «Una consecuencia de la peste negra en Cataluña: el pogrom de 1348» Sefarad, Madrid, 1959, vol. 19 , pp. 92-131 e 321-364.

(') Maria José P. Ferro, ob. cit., pp. 60-64. 
da judiaria grande de Lisboa $\left({ }^{7}\right)$. No entanto, estes acidentes, em princípio, nada teriam a ver com qualquer reacção antijudaica por parte do exército invasor, mas sim com a localização daqueles bairros no espaço concelhio mais afectado pela passagem e permanência dos homens de Henrique de Trastâmara.

Em 1378, a comuna de Leiria obtinha de D. Fernando carta de segurança porquanto "fizerom certo per stromento publico feito per tabelliam do muito mal e dampno que recebiam dos christaãos dessa villa ao dia de quinta feyra e da sesta feira maior d'endoenças, e que lhe (sic) britam as portas das casas em que moram e as paredes pera lhes filharem o que teem e lhes fazem mal e dampno nos corpos e que pero vos (alcaide e juízes de Leiria) frontam e dizem que o stranhedes aaquelles que lhe esse mal e dampno fazem que nom queredes hi tornar na maneyra que devedes o que nos nom avemos por bem. E enviaram nos pedir por mercee que lhe ouvesemos a ello alguũ remedio per que nom recebesem os dictos dampnos nem outra sem razam em nos dictos dias" $\left({ }^{8}\right)$. O soberano proibia que tal sucedesse, sob pena de 10 libras a todo aquele que tal acto praticasse. Punha, porém, como condição que «nehuũ judeu nem judia nom saya fora pollo dicto dia d'endoenças".

Ora esta tentativa de destruição de pessoas e bens por parte dos cristãos, na semana da paixão tinha um móbil religioso, provocado pelo climax que atingiam as cerimónias religiosas da semana santa, exacerbadas pelo tom fanático de algumas pregações, feitas no seu decurso. No entanto, o próprio teor da carta não nos permite concluir se tais actos eram isolados, praticados por um ou outro indivíduo mais fanatizado, ou se teriam origem em uniões populares contra a comunidade judaica. Em qualquer dos casos, as autoridades municipais recusavam-se a actuar contra os atacantes dos judeus, talvez receando tumultos maiores, em que o reinado fernandino foi fértil e a que Leiria não foi alheia $\left(^{9}\right)$.

(') A.N.T.T., Chancelaria de D. Fernando, liv. 1, fls. 128 e 140 v; Chancelaria de D. Duarte, liv. 1, fls. 193-193 v; Fernão Lopes, Crónica de D. Fernando, Porto-Barcelos, Livraria Civilização, 1966, p. 204; Maria José P. Ferro Tavares, Os Judeus em Portugal no século XV, pp. 70-71 e 419 .

$\left.{ }^{8}\right)$ A.N.T.T., Chancelaria de D. Fernando, liv. 2, fls. 26- 26v; liv. 4 , fl. 26.

${ }^{\circ}$ ) Veja-se: Maria José P. Ferro, «A revolta dos mesteirais de 1383», in Actas das III Jornadas Arqueológicas-1977, Lisboa, 1978, vol. I, pp. 359-383. 
Em Dezembro de 1383, o povo miúdo de Lisboa tentaria, sem êxito, assaltar a judiaria grande da cidade. Mais do que motivações religiosas, a causa próxima era o clima de instabilidade política que se seguiu à morte de D. Fernando e, depois, ao assassinato do Andeiro, durante a curta regência da rainha viúva Leonor Teles. No inconsciente colectivo dos "pequenos», estavam anos de opressão, provocada pelos judeus ricos, colectores de impostos e os seus oficiais, também, judeus. D. Judas Aben Menir, rabi mor e tesoureiro mor do reino, e David Negro, almoxarife de Lisboa, eram o símbolo desse poder da minoria judaica sobre a maioria cristã. Era o ódio do oprimido contra o opressor, do colectado contra o colector, do pobre contra o rico que, neste caso, assumia também a figura da minoria religiosamente detestada, assimilada nos seus mais altos representantes ao domínio político rejeitado: a Rainha e Castela. Fernão Lopes escreveria: «.... e comtamdo cada huũ o que lhe pareçia de taaes feitos naçeo entrelles huũ novo acordo, dizemdo que era bem de rroubar alguũs Judeus rricos da Judaria, assi como dom Yuda que fora Tesoureiro moor delRei dom Fernando, e dom Davi Negro, que era gramde seu privado e outros; e que destes poderia aver o Meestre mui gram rriqueza pera soportamento de sua homrra" $\left({ }^{10}\right)$.

Eles eram "traidores» e possuiam "gramdes tesouros escomdidos» ( $\left.{ }^{11}\right)$. A defender a minoria judaica saiu a nobreza portuguesa que estava com o Mestre de Avis. Os condes D. João Afonso Telo e D. Alvaro Peres de Castro foram bem claros ao pedirem àquele, protecção para os judeus de Lisboa, onde se distinguiam altos dignitários cortesãos como eles, "ca depois que começarem seervos ham mui maaos de desviar de tall feito" $\left.{ }^{12}\right)$. De facto, o Mestre, ao chegar à judiaria encontrou "gram parte dos da çidade que sse juntavom quamto podiam; e todos alvoraçados pera emtrarem demtro e a rroubarem» $\left({ }^{13}\right)$.

Esta é a primeira narrativa que conhecemos de uma união contra os judeus, sem qualquer consequência, porquanto abortaria, graças à pronta acção da nobreza e do novo "chefe" popular. Teria sido a única nestes tempos tão conturbados e com levantamentos populares tão frequentes em várias zonas do reino? Fernão Lopes só a esta se referiu e a documenta-

$\left({ }^{10}\right)$ Fernão Lopes, Crónica del Rei dom João primeiro de boa memória, Lisboa, Imprensa Nacional-Casa da Moeda, 1973, vol. I, p. 29.

(11) Ibidem, p. 30.

('i2) Ibidem.

(') Ibidem. 
ção régia é muda a tal respeito. Até meados do século seguinte, não conhecemos asto semelhante, apesar do ano de 1391 ter sido fértil em revoltas contra os judeus, em Castela e Aragão $\left({ }^{14}\right)$. Portugal ter-se-ia limitado a receber os fugitivos baptizados ou não. Os monarcas $D$. João I e D. Duarte, numa medida proteccionista, promulgariam leis que confirmavam a segregação física e espacial entre judeus e cristãos e limitavam a sua acção, quer como oficiais do rei, quer como rendeiros dos direitos reais e colectores de impostos. Procurava-se, evitando o domínio dos judeus sobre os cristãos, que estes crescessem em sentimentos antijudaicos.

Mas, em fins de Dezembro de 1449, Lisboa seria, de novo, palco de uma união contra os judeus. A causa próxima, segundo Rui de Pina, teria sido certos actos ofensivos que alguns moços cristãos fizeram "por travesura" em alguns judeus que se encontravam na Ribeira. Tendo-se estes queixado às autoridades judiciais cristãs, estas mandaram «pubrycamente açoutar alguns delles, de que algum povo meudo e as volltas delle outras jentes que eram na Cidade, assy se escandallizaram dos judeus, que sem mays outro acordo nem conselho, antes com grande oniam e alvoroço, dizendo matallos e rouballos, cometeram a judaria pella porta que vem ao poço de Fotea, e a roubaram toda atee o Poyo, em que dos judeus que se punham em registencia ouve alguus mortos, ao qual insulto logo acudiram com muyta força os Ofycyaaes da Justiça, e principalmente Dom Alvaro Conde de Monsanto, que com suas forças atalharam ho mais roubo, e dano que se detriminava fazer" $\left({ }^{15}\right)$.

Mais uma vez a judiaria grande ou velha na parte onde habitavam os grandes mercadores judeus e privados do rei era alvo de cobiça, desta vez com menor fortuna para os seus habitantes que foram roubados, feridos e alguns, que maior oposição mostraram, mortos.

De facto, a proximidade da quadra natalícia pois, segundo Baquero Moreno, estes acontecimentos teriam ocorrido a 23-24 de Dezembro $\left({ }^{16}\right)$, deve ter contribuído para o aumento de toda esta emotividade, elevada ao rubro pelo facto de cristãos terem sido castigados por causa de judeus. Na

(14) Maria José P. Ferro Tavares, Os judeus em Portugal no século $X V$, p. 420 , nts. 173 e 174.

$\left.{ }^{15}\right)$ Rui de Pina, «Chronica d'el Rey D. Affonso V», in Colleç̧ão de Livros Ineditos de História Portugueza, Lisboa, 1790, vol. I, pp. 439-440; $\mathrm{H}$. Baquero Moreno, $O$ assalto à judiaria grande de Lisboa em Dezembro de 1449, sep. Revista de Ciências do Homem, Lourenço Marques, 1970, pp. 10-11; Maria José P. Ferro Tavares, ob. cit., p. 421.

(io) Baquero Moreno, ob. cit., p. 15. 
sua mentalidade, era difícil aos cristãos compreenderem o exercício imparcial da justiça, mesmo quando esta caía sobre o "povo de Deus», acusado de crime em indivíduos da minoria odiada porque deicida. Por isso, o "povo miúdo" de Lisboa se escandalizou por tão crua justiça se abater sobre os culpados. Era o sentido pejorativo que os cristãos tinham dos judeus, que os levava a tal reacção. Daí que nem o próprio rei fosse acatado e "contra sua Real pessoa se allevantaram oniōes tam irosas, que ouve por bem seçar de fazer mais cruas execuções» $\left({ }^{17}\right)$.

A 6 de Outubro de 1450, D. Afonso V concedia o perdão a todos quantos participaram nestes actos, com excepção de Pedro de Lepe, Pedro do Couto e João Carvalho $\left({ }^{18}\right)$, provavelmente uns dos cabecilhas do movimento que, juntamente com outros foram condenados, "por o dito maleficio em si seer tam maao e cousa que nunca foy em nossos regnos aconteçida, de que se seguyo afora o damno e perda que os ditos judeos ouverom, grande ofensaa a nossa justiça e doesto e abatimento a alguũs moradores da dita çidade aynda que per feito em o dito malifiçio nom fossem culpados soomente por comsentirem e leixarem roubar a gente tam refeçe e de tam baixa condiçom os ditos judeos que vivem no lugar honde elles vivem sob nossa defenssom" $\left.{ }^{19}\right)$. Só beneficiariam da amnistia real os culpados que no prazo de 60 dias a partir da data da publicação da carta que seria 10 de Outubro, viessem requerer carta de perdão e pagassem pelo crime cometido uma pena monetária variável, conforme a qualidade deste. Sobre os que assim não procedessem recaíria uma pena corporal que poderia ir até à pena de morte para os que continuassem fugidos à justiça, além do confisco dos bens $\left({ }^{20}\right)$.

Os assaltantes eram, na sua maioria, segundo as cartas de perdão, mesteirais $\left({ }^{21}\right)$, a tal gente "refeçe e de tam baixa condiçom", no dizer da carta de D. Afonso V. O móbil fora o roubo e este cifrou-se, em grande parte, em tecidos estran-

(") Rui de Pina, ob. cit., p. 440; Baquero Moreno, ob. cit., p. 11.

( $\left.{ }^{18}\right)$ Lx., A.H.C.M., Livro $20^{\circ}$ dos Reis D. Duarte e D. Afonso V, doc. n. 33; Livro dos Pregos, fl. 243, doc. 361; Baquero Moreno, ob. cit., pp. 16 e 39-40; Maria José Ferro Tavares, ob. cit., p. 421.

$\left.{ }^{19}\right)$ Lx., A.H.C.M., Livro $2 .^{\circ}$ dos Reis D. Duarte e D. Afonso V, doc. n..$^{\circ} 33$; Livro dos Pregos, fl. 243, doc. 361; Baquero Moreno, ob. cit., pp. 16 e 39-40; Maria José Ferro Tavares, ob. cit., p. 421.

$\left.{ }^{20}\right)$ Lx., A.H.C.M., Livro $20^{\circ}$ dos Reis D. Duarte e D. Afonso V; doc. n. 33; Livro dos Pregos, fl. 243, doc. 361; Baquero Moreno, ob. cit., pp. $39-40$.

$\left.{ }^{21}\right)$ Baquero Moreno, ob. cit., pp. 16-34 e 44-51; Maria José Ferro Tavares, ob. cit., pp. 421-422. 
geiros de vária qualidade e dinheiros. As mortes teriam sido meramente ocasionais e só em caso de oposição por parte dos judeus.

O levantamento teria deixado indiferentes outros habitantes da cidade e, porventura, até as próprias autoridades municipais: «o quall se fez per mingua ou negrijençia dos que emtom em a dicta cidade foram presentes que o bem poderam tolher e em todo arredar se quiserom» $\left({ }^{22}\right)$. Medo do povo miúdo, indiferença e alheamento das pessoas e bens dos judeus levavam os moradores de Lisboa, com certa responsabilidade nesta, a consentirem nos desmandos ocorridos.

Esta união, tal como a de 1383, caracterizou-se pela sua espontaneidade. Foi um acontecimento momentâneo, provovado pela ira popular e circunscrito no tempo e no espaço.

Em 1463, D. Afonso V, solicitado pelas comunas, confirmaria e mandaria publicar em todo o reino as bulas papais que permitiam aos judeus usufruirem da liberdade de culto, exercerem livremente a sua profissão e viverem em paz entre os cidadãos e nas judiarias. De facto, as cartas de Martinho V, dirigidas aos judeus da Península e que, de novo, eram aqui proclamadas, confirmavam o direito de:

- exercerem a medicina entre os cristãos, sem incorrerem nas penas postas pelo antipapa Bento XIII, por conselho do célebre converso Paulo de Santa Maria, arcebispo de Burgos $\left({ }^{23}\right)$;

- serem corretores, procuradores de cristãos, cambiadores, rendeiros e recebedores de rendas, de fazerem contratos e estabelecerem sociedades com os cristãos, terem as suas lojas e comércio na zona cristã, conviver e acompanhar os cristãos pelos caminhos.

Proibia os assaltos às judiarias para matar e roubar os seus habitantes, assim como a destruição das sinagogas. Libertava os judeus da assistência às pregações nos templos cristãos e recusava o baptismo de um judeu, menor de doze anos.

Martinho $\mathrm{V}$ interessava-se igualmente pelos conversos e a situação da esposa judia que não acompanhava o marido na abjuração da sua antiga fé $\left({ }^{24}\right)$.

(22) Lx., A.H.C.M., Livro $20^{\circ}$ dos Reis D. Duarte e D. Afonso V, doc. n. 33 ; Livro dos Pregos, fl. 243, doc. 361 .

(2) J. Amador de los Rios, Historia de los judios de España y Portugal, 2. ${ }^{\mathrm{a}}$ ed., Madrid, Aguilar, 1973, pp. 538-542 e ap. doc. XX, p. 970.

(2) A.N.T.T., Chancelaria de D. Afonso V, liv. 9, fls. 99-99 v; Maria José Ferro Tavares, ob. cit., pp. 434-435. 
As conversões, mais frequentes a partir da década de cinquenta, teriam algo a ver com a insegurança, sentida pelos judeus? Ou seriam os novos conversos mais prontos a odiar os seus antigos irmãos na fé e a chamarem sobre estes a animosidade dos cristãos? Teriamos tido, sem os conhecermos, vários Paulo de Santa Maria?

De facto, alguns destes conversos entraram na vida religiosa. Assim, frei Afonso de Jesus, monge professo em Alcobaça $\left({ }^{25}\right)$, frei Vicente de Lisboa, monge dominicano $\left({ }^{28}\right)$, mestre Paulo, pregador em Braga $\left({ }^{27}\right)$, Afonso Fernandes de Santiago, professo em Alcobaça $\left({ }^{28}\right)$, todos religiosos na década de sessenta. Igualmente, durante este período, teriam ocorrido algumas conversões forçadas, de que nós não sabemos, hoje, distinguir o seu grau de excepcionalidade, embora nos inclinemos para ele. Foi o caso de um judeu de Portalegre, obrigado a receber o baptismo, por um grupo de cavaleiros e escudeiros, encabeçado por Gonçalo Vasques de Castelo Branco $\left({ }^{29}\right)$. Conversões forçadas ou, pelo menos, não assumidas por um dos moços, teriam sido as dos dois moços da comuna de Leiria que partiram com Simão de S. Mateus $\left({ }^{30}\right)$.

Contemporâneas deste lento crescer do sentimento antijudaico foram as constituições sinodais bracarenses que viriam a ter lugar em $1477\left({ }^{31}\right)$ e que devem ter sido contemporâneas das pregações de frei Paulo, em Braga: Este converso recebeu as ordens menores em $1464\left({ }^{32}\right)$ e, no ano seguinte, a "prima tonsura" ( $\left.{ }^{33}\right)$. A 27 de Agosto de 1466 tornar-se-ia abade da igreja de Sequiade, na terra de Penafiel ( ${ }^{34}$ ). Mais tarde, em 1481, seria conhecido e temido pelo ardor que punha nas suas pregações antijudaicas e que provocavam "levantos e onyoees contra os judeus" na comarca de

$\left.{ }^{25}\right)$ A.N.T.T., Dourados de Alcobaça, liv. 3, fls. 35v-37.

$\left({ }^{20}\right)$ Ibidem, liv. 9, fl. 62.

${ }^{(27)}$ H. Baquero Moreno, Novos elementos relativos a mestre Paulo, pregador do século XV, contra os judeus bracarenses, sep. de Bracara Augusta, Braga, 1978, pp. 8-12; José Marques, $A$ contenda do cabido com os judeus de Braga na segunda metade do século $X V$, sep. de Altitude, Guarda, 1983, p. 17; Maria José Ferro Tavares, ob. cit., p. 437 .

( $\left.{ }^{28}\right)$ A.N.T.T., C.R., Mosteiro de Alcobaça, m. 12, n. 294.

${ }^{20}$ ) A.N.T.T., Chancelaria de D. Afonso V, liv. 28, fls. 121-121v; Maria José Ferro Tavares, ob. cit., p. 442.

${ }^{\left({ }^{30}\right)}$ A.N.T.T., Chancelaria de D. Afonso V, liv. 36, fl. 118; Maria José Ferro Tavares, ob. cit., p 442.

(11) José Marques, ob. cit., p. 20.

$\left.{ }^{32}\right)$ Baquero Moreno, ob. cit., p. 11, doc. n.० 1.

$\left.{ }^{33}\right)$ Ibidem, doc. n. 2 e 3.

$\left(^{34}\right)$ Ibidem, p. 12, doc. n. 4. 
Braga $\left({ }^{35}\right)$. Durante as suas pregações nesta cidade e, certamente também noutros lugares, os judeus eram coagidos a assistir às suas pregações e aos que recusassem, devia ser-lhes negada casa pelos cristãos, sob pena de excomunhão $\left({ }^{36}\right)$. Ignoramos o ano em que se tornou conhecido como pregador, mas certamente seria antes de Janeiro de 1481, mês e ano das duas cartas régias, referentes à sua actuação em Braga. Seria curioso sabermos em que medida as constituições sinodais de 1477, naquilo que elas mais têm de antisemitismo, assim como as constituições 13 e $69\left({ }^{37}\right)$, não seriam o reflexo da influência de mestre Paulo e da sua palavra, uma vez que, com certa probabilidade, teria estado presente no sínodo diocesano. A sua força devia ser tão grande na diocese que o vigário geral ameaçava de excomunhão os cristãos que convivessem e dessem casa aos judeus que não assistissem às suas pregações...

Um clima de desconfiança começara a instalar-se nas relações entre a maioria cristã e a minoria judaica, na segunda metade do século XV. Mais do que motivos religiosos era o crescer do antagonismo económico entre ambos, em que a maioria se encontrava dominada por uma minoria de judeus cortesãos, membros da alta finança internacional. Os seus protestos bem se faziam ouvir nas cortes deste período, sem qualquer resultado imediato.

Entretanto, na vizinha Castela cresciam as perseguições contra os judeus e os conversos, forçando uns e outros a emigrar. A implantação da Inquisição e a expulsão dos judeus, primeiro da Andaluzia, depois de todo o reino, em 1492, acaria por provocar um forte movimento migratório e a sua fixação noutras zonas da Península, nomeadamente em Portugal. Este acréscismo abrupto de gente estrangeira e da minoria odiada abalou o frágil equilíbrio existente entre a maioria cristã e a minoria judaica, em Portugal. A agravar a situação estava a peste e o seu cortejo de medos e superstições.

O reinado de D. João II assistiu ao avolumar e ao radicalizar desta questão social. Para defender a minoria judaica portuguesa, o monarca praticaria uma política extremamente legalista, confinando os judeus aos seus bairros, proibindo- Thes o luxo excessivo, cerceando os privilégios pessoais de

${ }^{(35)}$ Baquero Moreno, As pregações de mestre Paulo contra os judeus bracarenses nos fins do século XV, sep. de Bracara Augusta, Braga, 1976, pp. 8-12.

${ }_{\left({ }^{36}\right)}$ Ibidem, p. 11 , doc: n. ${ }^{\circ} 1$.

$\left.{ }^{37}\right)$ José Marques, ob. cit., pp. 20 e 22. 
tipo social, etc. A instabilidade instalara-se também nas comunidades judaicas com a vinda dos castelhanos, em número demasiado elevado para o espaço físico que aquelas ocupavam no concelho e que, ainda por cima, se recusavam a respeitar as ordens dos magistrados comunais portugueses.

A correspondência oficial de Lisboa, Porto e Évora com D. João II mostrava bem o aumento do antijudaísmo. Este apresentava-se com dupla face: odiava-se o converso castelhano que arrastava consigo o estigma de criptojudaízante e o judeu. $\mathbf{O}$ povo, sobretudo, os "pequenos" estavam prontos a levantar-se à simples suposição de que tal castelhano era um falso cristão e as autoridades tinham dificuldade em contê-los. O medo viera para ficar. Receava-se o judeu deicida, o apóstata, a peste. Era um medo físico ao contágio, à doença, mas era também um medo psíquico. A peste era entendida como um castigo de Deus pelos pecados dos homens e, neste caso, por Portugal receber no seu seio os judeus e os conversos castelhanos.

O medo e o ódio eram tão sensíveis que, na carta enviada ao concelho de Lisboa, a 12 de Agosto de 1484, D. João II empenhava a câmara na defesa daqueles grupos "porque podia seer que por esta vullgar opinyam algũs sse moveriam a lhe fazer mall ou dapno e alevantar talvez per que se sigua contra elles alguũ gramde scandalon ${ }^{(38)}$.

A peste permaneceria no reino, durante todo este reinado, e encontramo-la nos principais centros relacionada com judeus e conversos.

Em 1481, o Porto expulsava, por um ano, os judeus que, vindos das pequenas comunidades dos arredores, trouxeram familiares mortos com a peste, para enterrar em Miragaia $\left({ }^{39}\right)$. Em 1484, o povo de Lisboa levantava-se contra os conversos castelhanos $\left({ }^{40}\right)$. A peste de 1487 rebentava em Evora, na judiaria o que levaria as autoridades municipais a encerrarem totalmente os judeus no seu bairro, o que era desusual. Contra este facto, D. João II ordenaria que só fossem fechadas «e taipadas as portas na maneira em que se faz na christendade honde alguũas pesoas faleçem e nom com mais gravezan $\left({ }^{41}\right)$.

${ }^{(38}$ Lx., A.H.C.M., Livro $10^{\circ}$ do Provimento da Saude, fl. 1; Maria José Ferro Tavares, ob. cit., p. 425.

${ }^{\left({ }^{\circ}\right)}$ Porto, G.H.C., Vereações, liv. 4, fl. 159; Maria José Ferro Tavares, ob. cit., pp. 425-426.

${ }^{\left({ }^{40}\right)}$ Lx., A.H.C.M., Livro $2^{\circ}$ de D. João II, fl. 40; Maria José Ferro Tavares, ob. cit., p. 426.

(11) Evora, A.D., Livro $2 .^{\circ}$ de Originais, fl. 225; Maria José Ferro Tavares, ob. cit., p. 426. 
1490 conheceria vários tumultos em Lisboa contra os judeus. Na carta de 15 de Julho, o soberano escrevia: "Nos fomos ora çertificado como neessa çidade fazem mujtos aluoroços e onyõoes comtra a comuna dos Judeus della. E assy por uos lhes som fectas ora nouamente mujtas enouaçõoes taaes em nenhũu tempo numca lhes forom fectas de que se causam os dictos aluoroços e onyõoes». E acrescentava: "Mas antes per Industrya dalgũas que neessa çidade teem hoffiçios se mouem contra elles cousas nouas que dam aazo a sse faze. rem as dictas onyõoes. E auer escandallo comtra elles e o poboo" $\left({ }^{42}\right)$. Responsabilizando as autoridades se houvesse algum levantamento contra a comuna, proibia todas as posturas camarárias que iam contra as liberdades, usos e costumes dos judeus de Lisboa. Na sequência da carta régia, aquelas tomariam uma série de medidas preventivas, atinentes a conter a agressividade dos cristãos e que seriam elogiadas pelo soberano. De novo, este recomendaria aos procuradores dos mesteres que avisassem "cada huũ em seu esprital ao povoo de vosso mester que nom consintam nenhuũ alvoroço" $\left({ }^{43}\right)$.

Ignoramos que medidas teriam sido tomadas pelo concelho e qual a proporção dos tumultos contra os judeus de Lisboa que elas provocaram. Sabemos, contudo, que entre os autores destes estava o povo miúdo, os homens dos mesteres e, certamente, não alheia eles, a peste que, neste verão, grassou na cidade $\left({ }^{44}\right)$.

A vigilância aumentou com a criação de quadrilhas para guarda da judiaria. Reforçaram-se as leis segregacionistas, proibindo aos cristãos comerciar no interior desta e aos judeus residir no seu exterior, porque "toda cousa donyam se deue darredar» $\left({ }^{45}\right)$.

Em 1492, entravam em Portugal os judeus castelhanos expulsos pelos Reis Católicos, uns em trânsito e outros, as 600 casas, para aqui se fixarem. Com eles ateava-se de novo a peste, sendo a Beira a primeira região a ser atingida pelo fiagelo $\left({ }^{48}\right)$.

('2) Livro das Posturas Antigas, transc. de Maria Teresa Campos Rodrigues, C.M.L., Lisboa, 1974, pp. 193-194; Maria José Ferro Tavares, ob. cit., pp. 426-427.

${ }^{\left({ }^{43}\right)}$ Lx., A.H.C.M., Livro $3 .^{\circ}$ de D. João II, fl. 21; Maria José Ferro Tavares, ob. cit., p. 427.

(4) Maria José Ferro Tavares, ob. cit., pp. 425 e 427.

("5) Lx., A.H.C.M., Livro 3.० de D. João II, fl. 23; Livro de Leis e Posturas, pp. 179-180; Maria José Ferro Tavares, ob. cit., p. 427.

${ }^{*}$ ) Lx., A.H.C.M., Livro $10^{\circ}$ do Provimento da Saude, fl. 12: Maria José Ferro Tavares, ob. cit., p. 427. 
Não sabemos se a sua entrada, apesar de ser contrária à opinião da maioria dos membros do conselho real, provocou alterações na ordem pública, embora as autoridades municipais reagissem negativamente e, por vezes, contra a vontade régia, tivessem recusado recebê-los como foi o caso de Évora $\left({ }^{47}\right)$.

A morte de D. João II, o sentimento antijudaico era cortante. Pelas cartas de 24 e 27 de Outubro de 1495, emitidas por D. Leonor e pelo novo rei, sabemos que o ambiente era propício a levantamentos contra as comunas, pelo que alertavam os concelhos a desenvolver uma vigilância apertada ${ }^{48}$ ).

Em conclusão, podemos dizer que as revoltas contra os judeus e até mesmo, a de 1506 , contra os cristãos novos de Lisboa, teve subjacente ao antagonismo religioso a concorrência económica existente entre a minoria judaica e a maioria cristã, em que aquela se afirmava de modo relevante nos grandes empreendimentos "capitalistas", quer nos arrendamentos dos direitos reais e de particulares, quer nas sociedades comerciais com nacionais e estrangeiros, quer na exploração dos monopólios reais do reino e do ultramar.

A medida que os concelhos se afirmavam e crescia neles uma burguesia urbana, ligada ao comércio e ao artesanato, cuja voz se fazia ouvir num "crescendo" cada vez mais elevado nas cortes e na exigência de medidas restritivas ao labor comercial e artesanal dos judeus, aumentava igualmente o antagonismo contra o judeu. Por isso, não estranhemos que a comunidade judaica mais martirizada tivesse sido a de Lisboa, apesar de os raros levantamentos aqui ocorridos não se poderem comparar, nas suas proporções, com os que sucederam noutros reinos europeus e peninsulares, durante a Idade Média. O fanatismo religioso nunca se revelou marcante em Portugal, mas sim uma excepção, como a ocorrida em Braga com as pregações de um frei Paulo, ou com as atitudes de um grupo de fidalgos em Portalegre, ou até na Lisboa de 1506 , contra os cristãos novos.

O roubo mais do que a conversão e a vida, foi o «leit motiv" principal das uniões contra os judeus. Estes eram os ricos, eram os colectores de impostos, eram os usurários, eram os verdadeiros "capitalistas» portugueses. E esta ideia esteve presente em 1383, em 1449 e em 1506... Os restantes levantamentos que nós vagamente conhecemos, tiveram como

("7) Evora, A.D., Livro 3:० de Originais, fl. 212; Maria José Ferro Tavares, ob. cit., p. 428.

${ }^{\left({ }^{8}\right)}$ Maria José Ferro Tavares, ob. cit., pp. 429-430. 
raiz toda uma instabilidade económica, física e psíquica, decorrente do clima existente no reino vizinho e da expulsão dos judeus castelhanos e da fixação aqui de algumas dessas famílias. $\mathbf{O}$ valor económico e artesanal destas aumentou o peso do braço judaico em detrimento do cristão. Sabe-se o apreço com que D. João II recebeu os mesteirais, expertos nas artes bélicas e na metalurgia, por exemplo.

A agravar este factor já de si fonte de rivalidade e de ódio, temos a peste, presença constante neste final do século XV e, também, em 1506. O judeu sofreu sempre com a instabilidade emocional criada pelas epidemias. Lembremo-nos do ocorrido em 1348, em que várias comunidades da Europa foram destruídas. Ao medo da morte e da peste, juntava-se a ideia de que era o judeu o seu causador. Tal como matara o Messias, procurava agora destruir os "filhos de Deus». A esta noção física da destruição dos cristãos pela doença, acresıia a do castigo dos pecados e estes eram, sem sombra de dúvida, causados pelo facto de, entre aqueles, o rei permitir que vivessem judeus e conversos, perseguidos pela Inquisição castelhana, por apóstatas. 